\title{
Morfolojik Açıdan Arap Dilinde Illhâk Olgusu
}

\section{The Phenomenon of Annexation in the Arabic Language in Morphological Terms}

\author{
Fatih ULUGÖL \\ Dr. Öğr. Üyesi, Kocaeli Üniversitesi Illahiyat Fakültesi, Arap Dili ve Belagati \\ Asst. Prof., Kocaeli Universty, Faculty of Theology, Department of Arabic Language and Literature \\ Kocaeli, Turkey \\ mfatihulugol@gmail.com \\ orcid.org/0000-0002-5612-6505
}

\author{
Makale Bilgisi / Article Information \\ Makale Türü / Article Types : : Araştırma Makalesi / Research Article \\ Geliş Tarihi / Received : : 18 Eylül / September 2021 \\ Kabul Tarihi / Accepted $\quad$ : 24 Kasım / November 2021 \\ Yayın Tarihi / Published : : 15 Aralık / December 2021 \\ Yayın Sezonu / Pub Date Season : Aralık / December \\ Cilt / Volume: 8 - Sayı / Issue: 2 - Sayfa / Pages: 559-578 \\ Atıf / Cite as \\ Ulugöl, Fatih. "Morfolojik Açıdan Arap Dilinde İlhâk Olgusu". Bülent Ecevit Üniversitesi Illahiyat Fakültesi Dergisi 8/2 \\ (2021), 559-578. \\ Doi: 10.33460/beuifd. 997299 \\ İntihal / Plagiarism \\ Bu makale, en az iki hakem tarafından incelendi ve intihal içermediği teyit edildi. \\ This article has been reviewed by at least two referees and scanned via a plagiarism software. \\ Yayın Hakkı / Copyright ${ }^{\circ}$ \\ CC BY-NC-ND 4.0 | Zonguldak Bülent Ecevit Üniversitesi, İlahiyat Fakültesi tarafından yayınlanmıștır. Telif ve yayın \\ hakları, Creative Commons Atıf-Gayri Ticari-Türetilemez 4.0 lisansının hüküm ve koşullarına tabidir. \\ CC BY-NC-ND 4.0 | Published by Zonguldak Bulent Ecevit University. Copyrights are subjected to the terms and conditions \\ of a Creative Commons Attribution-NonCommercial-No Derivatives License 4.0.
}

Öz: Arap dili morfolojisinde mezîd bâblar dışında, kendisinde bir veya iki harf ziyâde edilen bazı bâblar bulunmaktadır ki bunlara mülhak bâblar denmektedir. Bu bâblara uyarlanabilen kelimeler, sırf lafzî yönden başka kelimelere benzetilmek amacıyla oluşturulmuştur. Mülhak bâblar, kelimenin üç türünden sadece fiil ve isimlerde bulunmaktadır. Fiillerde rubâî mücerred ve rubâî mezîd bâblara yapılan ilhâklar, isimlerde ise rubâi mücerred, rubâî mezîd, humâsî mücerred ve humâsî mezîd bâblara yapılmaktadır. Mülhak bâblardan bazıları dilciler tarafından kıyâsî olarak kabul edilirken çoğunluğunun semâ'î olduğu ifade edilmiştir. İlk dönem dilcileri tarafından da ele alınan mülhak bâbların kullanılması bir taraftan Arap dilinin kelime zenginliğine katkı sağlamış, diğer taraftan özellikle şiirlerde vezin uyumu hususunda şairlere önemli kolaylıklar sunmuştur. Kendisinde bir ya da iki harf ziyâde edilmesi sûretiyle oluşturulan mülhak bâblar ile diğer mezîd bâblar dilciler tarafından farklı kategorilerde ele alınmıştır. Bunun en temel sebebi, mezîd bâblarda ziyâde edilen harflerin kelimeye farklı bir mana katmak amacıyla ziyâde edilmesi, mülhak bâblardaki ziyadenin ise sadece bir kelimeyi vezin olarak başka bir kelimeye benzetmek amacıyla yapılmış olmasıdır. Mülhak bâblar incelendiğinde kelimelerin başka bâblara rastgele uyarlanmadığı, kelimenin hangi türlerinde ilhâkın yapılacağı, kaç 
harfin ziyade edileceği, ziyade edilen harfin kelimenin neresine yerleştirileceği vb. hususlarda bazı temel ilkelerin gözetildiği anlaşılmaktadır. Bu çalışmada Arap dilindeki önemli olgulardan biri sayılan ilhâk konusu ele alınacak, mülhak bâbların kalıpları, ilhâkın amaçları, türleri ve harfleri incelenecektir.

Anahtar Kelimeler: Arap Dili, Ilhâk, Mülhak, Mülhakun Bih, Mezîd.

\begin{abstract}
In the morphology of the Arabic language, other than mazid patterns, there are certain patterns called mulhaq, which include one or two additional letters. Words originating from these patterns were created only to be likened to other words in literal terms. Out of the three types of words, mulhaq patterns are only present in nouns and verbs. In verbs, the annexations made to four-letter mujarrad (basic forms) and four-letter mazid patterns are made to four-letter mujarrad, four-letter mazid, five-letter mucerred and five-letter mazid patterns in nouns. Certain mulhaq patterns are regarded as grammatical by linguists while it was stated that most of them are auditory. The use of mulhaq patterns, which were also discussed by early-period linguists, contributed to the linguistic richness of Arabic on the one hand while also providing significant convenience to poets in terms of metric harmony, particularly in poems. Mulhaq patterns, which are created through the addition of one or two additional letters, and other mazid patterns were discussed under different categories by linguists. The main reason behind this is that the additional letters in mazid patterns are used to add a different meaning to the word while those in mulhaq patterns are used only to liken one word to another in metric terms. In the present study, the subject of annexation, which is regarded as one of the significant concepts in Arabic, will be discussed and the structures of mulhaq patterns will be examined as well as the purposes, types and letters of annexation.
\end{abstract}

Keywords: Arabic Language, Annexation, Mulhaq, Mulhaq Bih, Mazid.

\title{
Giriş
}

Arapça'da gerek isimler gerekse fiiller belli başlı kalıplara uyarlanabilmektedir. Dilciler tarafından tespit edilmeye çalışılan bu kalıplar farklı şekillerde sınıflandırılmıştır. Kelimenin mücerred (yalın) haline, mezîd (harf eklenmiş) haline, kök harflerinin sayısına ve ziyâde edilen harf sayısına göre yapılan tasnifler bunlardan bazılarıdır. Gramer kitaplarında fiillerin ve isimlerin kalıpları tanıtılırken ele alınan konulardan biri de mülhak bâblardır. Bir kelimeyi, kendisinden daha fazla harfe sahip başka bir kelimeye şekil olarak benzetme ve böylece yeni vezinler oluşturup dili zenginleştirme çabalarına matuf olan ilhâk konusu, Arap dili gramerinin oluşturulmaya başlandığı ilk dönemlerden itibaren ele alınmıştır. Nitekim kadîm Arap dilcilerinden Sîbeveyhi'nin (ö. 180/796) el-Kitab'ında, Müberred'in (ö. 286/900) el-Muktadab ve el-Kâmil'inde, İbnü's-Serrâc'ın (ö. 316/929) el-Usûl'ünde hem ilhâk kavramına hem de bu kavramla ifade edilen kalıplara rastlanmakta- 
dır. ${ }^{1}$ Bir taraftan mülhak olarak kabul edilebilecek kelimelerin tespiti, diğer taraftan bu kelimelerin sahip olduğu kalıpların kıyasa konu olup olamayacağı gibi birçok husus gerek kadîm dönemde gerekse sonraki dönemlerde dilciler tarafından araştırma konusu yapılmıştır. Ancak yukarıda adı geçen ve bunlar dışındaki birçok kadîm dil bilgininin eserlerinde her ne kadar mülhak kelimelere dair misaller verilip bu misallerin tahlilleri yapılmışsa da İbn Cinnî'ye (ö. 392/1002) gelinceye değin ilhâk kavramının efrâdını câmi ağyârını mâni olan net bir tanımı yapılmamış ve ilgili meseleleri tam olarak ele alınmamıştır. İbn Cinnî ise özellikle Ebû Osman el-Mâzinî'nin (ö. 249/863) et-Tasrîf isimli kitabını şerh ettiği el-Munsıf isimli eserinde konuyu geniş bir şekilde ele alıp ilhâkın tanımını yapmış, kalıplarını belirlemiş ve konuyu belli başlı kısımlara ayırarak her bir kısmı açıklamaya çalışmıştır. Aynı şekilde el-Hasâis adlı eserinde de konuya dair önemli bilgiler vermiş̧tir. ${ }^{2}$

Klasik eserlerde ele alınan ilhâk konusu incelendiğinde Arap dilinde bu konunun müstakil bir çalışma olarak ele alınmadığı görülmektedir. Sîbeveyhi'in el-Kitâb'ı, Müberred'in el-Muktadab'ı, İbnü's-Serrâc'ın el-Usûl'ü, İbnü'l-Verrâk'ın (ö. 381/991) Illelü'n-nahv'i, es-Semânînî'nin (ö. 442/1051) Şerhu't-tasrîfi, Abdulkahir el-Cürcânî'nin (ö. 471/1078-79) el-Miftâh'ı, Zemahşerî'nin (ö. 538/1144) el-Mufassal'ı, İbnü'I-Hâcib'in (ö. 646/1248) eş-Şâfiye'si, İbn Usfûr'un (ö. 669/1270) el-Mümti 'ü'l-kebîr'i, Ebû Hayyân'ın (ö. 745/1344) el-Mübdi'i, Hamlâvî'nin (ö. 1351/1932) Şeze'l-arf'ı, Muhammed Abdulhalik Udayme'nin (ö. 1403/1982) el-Muğnî́si, Nâsır Hüseyin Ali'nin es-Sıyağu's-sülâsiyye'si gibi eserlerde ilhâk konusu bazen belli bir başlık altında incelenmiş bazen de dağınık olarak yeri geldikçe konuya temas edilmiştir. Tespit edebildiğimiz kadarıyla ilhâk konusunu müstakil olarak farklı açılardan ele alan iki yüksek lisans çalışması ve bir de makale bulunmaktadır. Yüksek lisans çalışmalarından birincisi, Omdurman (Ümmüdürman) İslam Üniversitesi'nde Ayşe İbrahim el-Mehdî tarafından hazırlanan Zâhiretü'lilhâk fi's-sarfi'l-Arabî isimli çalışmadır. Diğeri ise Ümmü'l-Kurâ Üniversitesi'nde Mehdî b. Ali tarafından yazılan Ebniyetü'l-ilhâk fi's-Sıhâh adlı çalışmadır. Muhammed Said Salih ise yazmış olduğu Mefhûmu'l-ilhâk fi's-sarfi'l-Arabî isimli makale ile özellikle ilhâk hakkında yapılan tanımlara eleştirel bir bakış açısıyla yaklaşarak konunun bazı yönlerine ışık tutmaya çalışmıştır. Bu çalışmada ise öncelikle ilhâkla bağlantılı olan ziyâde konusuna değinilmiş, daha sonra ilhâkın ne olduğu, hangi kelime türlerinde, ne şekilde ve hangi harflerle meydana geldiği, ilhâkın semâ'î ya da kıyâsî olduğu, Arapların hangi amaçlarla böyle bir kelime türetme yoluna gittikleri, mülhak diye isimlendirilen bâbların mezîd olması ile diğer bâbların

1 Ebû Bişr Sîbeveyhi Amr b. Osmân b. Kanber el-Hârisî, el-Kitâb, thk. Abdusselam Muhammed Harun (Kahire: Mektebetu'l-Hâncî, 1988), 4/288; Ebu'l-Abbâs Muhammed b. Yezîd el-Müberred, el-Muktadab, thk. Muhammed Abdulhalık Azîme (Beyrut: Âlemu'l-Kütüb, ts.), 1/244; a.mlf. el-Kâmil fi'l-luga ve'l-edeb, thk. Muhammed Ebu'l-Fadl İbrahim (Kahire: Dâru'l-Fikri'l-Arabî, 1997), 3/80.

2 Osman b. Cinnî, el-Munsıf (y.y.: Dâru İhyâi't-Turâsi'l-Kadîm, 1954), 34-49; Mehdî b. Ali, Ebniyetü'I-ilhâk fi's-Sıhâh (Mekke: Ümmü'l-Kurâ, Külliyetü'l-Lüga el Arabiyye, Yüksek Lisans Tezi, 1996), 11. 
mezîd olması arasında nasıl bir ayrımın bulunduğu ve mülhak bâbların mezîd haliyle mücerred hali arasında ne tür bir ilişki olduğu hususları incelenerek alana katkı sunulması amaçlanmıştır.

\section{Kelimelerin Mücerred ve Mezîd Yapısı}

Arap dilinde mücerred kelime denince, içerisinde o kelimeyi oluşturan harfler dışında harf bulunmayan ve i'lâl durumu dışında kendisinden harf düşmeyen isim ve fiiller anlaşılır. ${ }^{3}$ Öyle ki bu harflerden biri kelimeden çıkarılırsa kelime anlamsız kalır. Örneğin sülâsî mücerred fiil dendiğinde o fiilin aslî harflerinin üç harf olup bu harfler içerisinde aslî harf dışında başka bir harfin bulunmadığı kastedilir. كََّّبَ شَرِبَ، حَسُنَ fiilleri gibi. Aynı şekilde rubâî mücerred fiil dendiğinde o fiilin aslî harflerinin dört harften oluştuğu ve bu harfler içerisinde aslî harflerin dışında başka

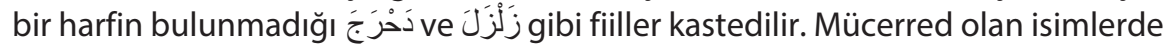
de durum aynıdır. Örneğin isimleri üç, dört ve beş harften oluşur ve bu harfler mezkûr isimlerin aslî harfleridir. Mezîd kelime ise aslî harfler dışında kendisinde bir veya daha fazla harf ziyâde edilen kelimelerdir. Sülâsî asıllı olan

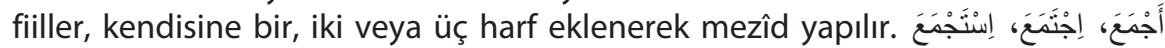
fiilleri gibi. Rubâî asıllı olan fiiller ise kendisine bir veya iki harf eklenerek mezîd yapılır. إحْرَنْجَمَ firilleri gibi. Sülâsî asıllı isimlere gelince bunlar, kendilerine

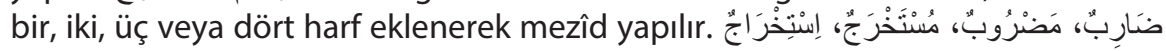
kelimeleri gibi. ${ }^{4}$

Mücerred fiillerde aslî harflerin sayısı ya üç ya da dörttür. Aslî harflerinin sayısı üçten az olamayacağı gibi dörtten çok da olamaz. Mücerred isimlerdeki aslî harf sayısı ise ya üç ya dört ya da beştir. Ayrıca fiiller, aslî harflere ziyâde edilen harflerle birlikte en fazla altı harfli olurken, isimler ziyâde edilen harflerle birlikte en fazla yedi harfli olur. ${ }^{5}$

\section{Ziyâde Türleri}

Dilcilerin, ziyâde kavramıyla ilgili yaptıkları "Kelimeye bir mana katmak veya dilde genişlik sağlamak (yeni kelimeler elde etmek) amacıyla kelimeye onda olmayan şeyi katmaktır. ${ }^{6}$ şeklindeki tanımdan da anlaşıldığı üzere Arapça kelimelerde yapılan ziyâdeleri iki kısma ayırmak mümkündür: Bunlardan birincisi kelimeye manevî katkı sağlayan ziyâde, diğeri ise kelimeye lafzî katkı sağlayan ziyâdedir. ${ }^{7}$

3 Ahmed b. Muhammed el-Hamlâvî, Şeze'l-arffîfenni's-sarf, thk. Nasrullah Abdurrahman (Riyad: Mektebetu'r-Rüşd, ts.), 21; Lübdî, Muhammed Semir Necîb, Mu'cemu'l-mustalahâti'n-nahviyye ve's-sarfiyye (Beyrut: Müessesetu'rRisale, 1985), 42.

4 Necmü'l-eimme Radıyyüddîn Muhammed b. el-Hasen el-Esterâbâdî, Şerhu'ş-Şâfiye, thk. Muhammed Nûr elHasan v.dğr. (Beyrut: Dâru'l-Kütübi'l-illmiyye, 1975), 1/9.

5 Hamlâvî, Şeze'l-arf, 54.

6 İbn Ya'îş, Muvaffakuddîn Yaîş b. Alî b. Yaîş, Şerhu'l-mufassal li'z-Zemahşerî, thk. Emîl Bedî’ Yakub (Beyrut: Dâru'lKütübi'l-IImiyye, 2001), 4/430.

7 Arap dilinde, kelimelerde yapılan ziyâdelerin yukarıda zikredilen amaçları dışında da belli başlı amaçları vardır. Örneğin kelimeye başlamanın mümkün olması için ziyâde edilen vasıl hemzeleri, hazfedilen harfe ivaz olarak ziyâde edilen harfler, vakfın mümkün olması için getirilen hâ-i sekt gibi harfler yukarıda zikredilen amaçlar dışında ziyâde edilen harflerdendir. Ali b. Muhammed el-Eşmûnî, Menhecü's-sâlik ilâ Elfiyyeti'bni Mâlik (Beyrut: Dâru'lKütübi'l-IIlmiyye, 1998), 4/54-55. 


\subsection{Kelimeye Anlam Açısından Katkı Sağlayan Ziyâde}

Bu ziyâde türünde, aslî harflerden oluşan kelimeye katılan harflerle kelimeye farklı bir anlam yüklenmiş olur. Örneğin sülâsî mücerred olan كَرَحُ (cömert oldu) fiilinin başında bir hemze ziyâde edilmesiyle fiil أَََْ şeklinde olur ki bunun manası "ikram etti" şeklindedir. Mücerred haliyle lâzım (geçişsiz) olan bu fiil mezîd olduğunda müteaddî (geçişli) bir fiile dönüşür. ${ }^{8}$ Aynı şekilde rubâî mücerred olan حَحْرَجَ (yuvarladı) fiilinin başında bir tâ harfinin ziyâde edilmesiyle fiil نَخَحَرَ (yuvarlandı) şeklini alır ki bu durumda fiil müteaddî iken lâzım fiile dönüşmüş olur. ${ }^{9}$ Bu tür ziyâdelerde kelimeye müteaddîlik-lâzımlık, çokluk, izâle etme, ortaklık, devamIılık, bir şeyi diğerine nispet etmek, bir yere yönelmek, sözü kısaltmak, bir şeye sahip olmak, mübalağa yapmak, bir şeyden kaçınmak, bir işi peyderpey yapmak ve bir şeyi talep etmek gibi manalar katılmış olur ki bu manalar sarf ilmine dair yazılmış olan kitaplarda detaylı olarak yer alır. Fiillerde olduğu gibi isimlerde de yeni bir mana elde etmek amacıyla bu tür ziyâdeler yapılır. Örneğin "نَاصِ kelimesinde ziyâde edilmiş olan elif harfi, yardım etme fiilini meydana getiren kişiyi ifade etmek için, ${ }^{10}$ "مَنْصُو kelimesinde ziyâde edilen mîm ve vâv harfleri yardım edilen kişiyi ifade etmek için, ${ }^{11}$ kelimesinin başında ziyâde edilen hemze yardım fiilini en fazla yapan kişiyi ifade etmek için ziyâde edilmiştir. ${ }^{12}$ Mücerred kelimelerde yapılan bu tür ziyâdeler her zaman farklı bir mana elde etmek için yapılır.

\subsection{Kelimeye Lafzî Katkı Sunan Ziyâde}

Bu tür ziyâdelerde ise asıl amaç yeni bir mana elde etmek değil, bir kelimeyi başka bir kelimeye kalıp/vezin olarak benzetmektir. ${ }^{13}$ Örneğin جَلْبَب (cilbab giydirdi) fiilinde ikinci bâ harfi zâiddir. Böyle bir ziyâdenin yapılmasındaki en temel amaç bu fiili نَحْرَ fiiline benzetmektir. Aynı şekilde هَهْدَد (bir kadın ismi) kelimesinin sonunda bulunan dâl harfi, bu ismi kalıp olarak جَعَفَُْ ismine benzetmek amacıyla ziyâde edilmiştir. Bu tür ziyâdelerde en temel gaye bir lafzı diğerine benzetmek olduğu için bu benzerliği ortadan kaldıracak işlemler bu kelimelerde yapılmaz. ${ }^{14}$ Örneğin yukarıdaki örneklerde vacip idgâm türünün şartları oluştuğu halde idgâm yapılmamıştır. Çünkü idgâm yapılması durumunda جَلْبَبَ fiili

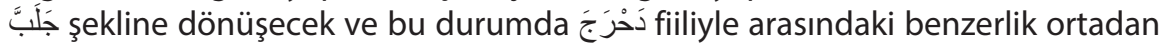
kalkacaktır.

8 Cemâlüddîn Abdullah b. Yûsuf b. Ahmed b. Abdillâh b. Hişâm el-Ensârî, Muğni'l-lebîb 'an kütübi'l-e ârî̀, thk. Mazin Mübarek-Muhammed Ali Hamdullah (Dimaşk: Dâru'l-Fikr, 1985), 678.

9 Maksûd (Mecmûatu's-sarf içinde), (İstanbul: Şifa yayınevi, 2011), 136.

10 Bahâuddin Abdullah İbn Akîl, Şerhu ibn Akîl alâ Elfiyyeti'bni Mâlik, thk. Muhammed Muhyiddin Abdulhamid (Kahire: Dâru't-Turâs, 1980), 3/134.

11 Şemseddin Ahmed İbn Kemâlpaşa, el-Felâh fî şerhi'l-Merâh (Dunkûz şerhiyle beraber Şerhân ale'l-Merâh kitabı içerisinde) (Mısır: Şeriketu Mektebeti ve Matbaati Mustafa el-Bâbî el-Halebî ve Evlâdih, 1959), 74.

12 Cemâlüddîn Abdullah b. Yûsuf b. Ahmed b. Abdillâh b. Hişâm el-Ensârî, Şerhu Katrin-nedâ ve belli's-sadâ, thk. Muhammed Muhyiddin Abdulhamid (Beyrut: el-Mektebetu'l-Asriyye, 2010), 312.

13 İbn Kemâlpaşa, el-Felâh, 102; Ayşe İbrahim el-Mehdî, Zâhiretü'l-ilhâk fi's-sarfi'l-Arabî (Sudan: Omdurman İslam Üniversitesi, Külliyetü'l-Lüga el Arabiyye, Yüksek Lisans Tezi, ts.), 15.

14 Ali b. Osman el-Akşehrî er-Rûmî, Telhîsu'l-Esâs (Şurûhu metni'I-Binâ içerisinde), (İstanbul: Şifa Yayınevi, 2014), 233. 


\section{Arap Dilinde Illhâk}

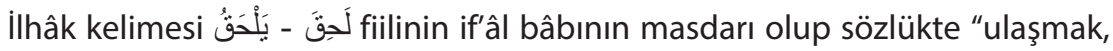
kavuşmak, ilave etmek, katmak, tabi kılmak, dâhil etmek" gibi anlamlara gelmektedir $^{15}$ ve kelime bu anlamlarıyla klasik gramer kitaplarında da kullanılmıştır. Sözgelimi Sîbeveyhi, Arapların yabancı olan kelimelerin Arapça'ya aktarılması durumunda bu kelimelerin Arapça kelime kalıplarına katıldığını ve benzetildiğini ilhâk kelimesiyle (ألحقوه بيناء كلامهم) ifade etmektedir. ${ }^{16}$ Terim olarak tarifine gelince; her ne kadar konunun temel esasları erken dönem dilcilerinin eserlerinde belirtilmiş olup pek çok örnek üzerinden açıklanmaya çalışılmışsa da ilmî bir tarifin en erken İbn Cinnî tarafından yapıldığı görülmektedir. Daha sonra gelen dilciler ise bu tarifi ya aynen korumuş ya da genişletmişlerdir. Morfolojik bir terim olarak ilhâk, İbn Cinnî tarafından şu şekilde açıklanmaktadır: "Illhâk, kelimeye harf eklemek sûretiyle yapılıp bu sayede kelime mülhakun bih'in veznine ulaşır. Bu da dilde bir tür genişlik (tevessü') sağlamak içindir."17 Radıyyüddîn el-Esterâbâdî́nin (ö. 688/1289'dan sonra) yaptığı şu tanım İbn Cinnî́nin tanımıyla örtüşmekle birlikte daha geniştir: "ỉsim ve fiilde ilhâkın manası, kelimeye bir mana ifade etme hususunda genel geçer olmayan bir veya iki harf eklemendir. Böylece o kelime bu ekle beraber harf sayısı, belirli harekeler ve sükûnlar hususunda başka bir kelime gibi olur."18 İbn Akîl (ö. 769/1367) de hem lafız hem mana yönünü göz önünde tutarak şöyle bir tanım yapmıştır: "Ilhâk, bir mana elde etmek amacıyla değil de bir kelimeyi diğerine denk kılmak ve böylece mülhak kelimeyi mülhakun bih olan kelime gibi tasrif etmek amacıyla kelimenin aslî harflerine bir harf ziyâde etmendir."19 Sabbân (ö. 1206/1792) da buna benzer bir şekilde ilhâkı şöyle tanımlamıştır: "Ilhâk, harf sayısı daha az olan bir kelimenin kendisinden daha fazla harfe sahip olan bir kelimeye denk kılınıp harf sayısı, belirli harekeler, sükûnlar, cem-i teksir ve tasğîr gibi hükümlerde onunla aynı kılınmasıdır."20 Râcî Esmer de ilhâkı "Fiil veya ismin aslî harflerine bir ya da iki harf eklemektir. Bu ekleme, mezid kelimenin harf sayısı, hareke ve sükûnlar yönüyle şekil olarak başka bir kelimeye benzemesi içindir." ${ }^{21}$ şeklinde tanımlayarak yukarıdakilere benzer bir tanım yapmıştır.

15 Cevherî, İsmail b. Hammâd, Mu'cemu's-Sihâh (Beyrut: Daru'l-Marife, 2012), "I-h-k", 941; Ebü'l-Fazl Cemâlüddîn b. Manzûr Muhammed b. Mükerrem b. Alî b. Ahmed, Lisânu'I-Arab (Beyrut: Dâru Sâdır, 1994), "I-h-k", 10/327; Muhammed b. Yakub Fîrûzâbâdî, el-Kâmûsu'I-muhît (Beyrut: Dâru'l-Erkam b. Ebi'I-Erkam, ts.), "I-h-k", 1181; İbrahim Mustafa vd., el-Mu'cemu'l-vasit (b.y.: y.y., ts.), "I-h-k", 871.

16 Sîbeveyhi, el-Kitâb, 4/303.

17 İbn Cinnî, el-Munsıf, 34.

18 Radî el-Esterâbâdî, Şerhu'ş-Şâfiye, 1/52.

19 İbn Akîl, Şerhu Ibn Akîl alâ Elfiyyeti'bni Mâlik, 4/261.

20 Ebü'l-İrfân Muhammed b. Alî es-Sabbân el-Mısrî, Hâşiyetü's-Sabbân ala şerhi'l-Eşmûnîala Elfiyyeti'bni Mâlik (Beyrut: Dâru'l-Kütübi'l-illmiyye, 1997), 2/127.

21 Râcî Esmer, el-Mu'cemu'l-mufassal fî ilmi's-sarf (Beyrut: Dâru'I-Kütübi'l-IIlmiyye, 1997), 152. 
Yukarıda verilen ve hemen hemen aynı manaları ifade eden tanımlardan anlaşıldığı üzere ilhâk yapılırken kelimeye, ondan olmayan bir harf eklenmekte, böylece o kelime daha fazla harfe sahip olan başka bir kelime gibi kılınmaktadır. İlhâk adı verilen bu işlemde kendisine harf eklenen kelimeye mülhak, bu kelimenin benzetilmek istendiği diğer kelimeye ise mülhakun bih denmektedir.

Fiillerde ilhâk yapıldığında mülhak olan fiil; masdarı, mâzî fiili, muzârî fiili, emir fiili, ism-i fâil ve ism-i mef'ûl kalıbı gibi hususların tamamında mülhakun bih

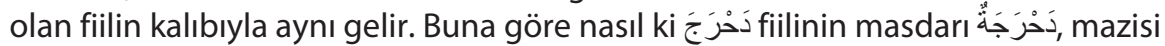

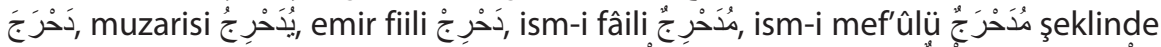

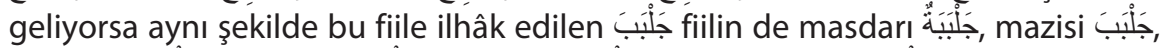

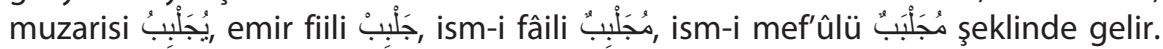
Böylece mülhak olan fiil; harf sayısı, hareke ve sükûnların tertibi yönüyle mülhakun bih olan fiil ile tam bir benzerlik göstermiş olur. Şu kadar var ki حَحْرَجَ filinin sonundaki cîm harfi ikinci lâmu'l-fiil olarak fiilin aslî harfi iken جَلَبَبَ filinin sonundaki bâ harfi ise aslî bir harf olmayıp ilhâk gayesiyle ziyâde edilmiş̧tir.

İsimlerde ilhâk yapılması durumunda ise mülhak olan isim; cem-i teksîr, ism-i

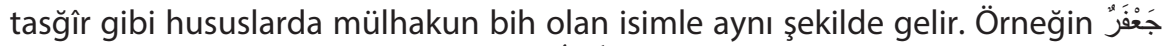
(küçük nehir) kelimesine mülhak olan قَرْْدَدُ (yüksek ve sert olan yer, dağ) kelimesi,

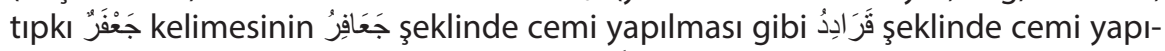
lır. Görüldüğü üzere her iki kelime de فَعَالِلْ vezninde cemi yapılmıştır. Ne var ki

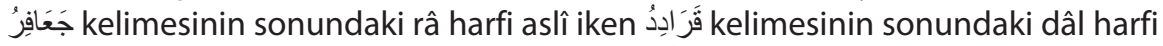

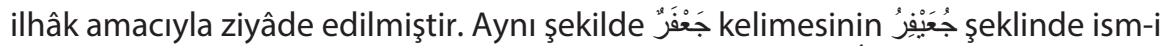

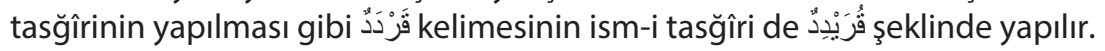

Yukarıda mülhak kelime ile mülhakun bih olan kelime arasında bir benzerliğin meydana geldiği ifade edildi. Ancak bu benzerlik, sarf ilminde kelimelerin kalıpları ele alınırken kullanılan vezin (el-mîzânü's-sarfî) hususunda bir benzerlik anlamına gelmemektedir. ${ }^{22}$ Buradaki benzerlik ve vezin birliğinden kasıt her iki kelimenin harf sayısı ile hareke ve sükûnların tertibi açısından aynı olmasıdır. Bu yönüyle de buradaki vezin birliği, tıpkı ism-i tasğîr konusunda kullanılan vezinden kastedilen duruma benzemektedir. ${ }^{23}$

\subsection{Fiillerde Iilhâk}

Fiillerde yapılan ilhâklardan biri rubâî mücerred bâbına, ikisi ise rubâî mezîd

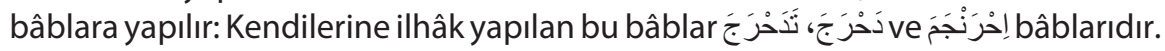

22 el-Mîzânü's-sarfî hakkında geniş bilgi için bk. Fahruddin Kabâve, Tasrîfü'l-esmâ ve'l-ef'âl (Beyrut: Mektebetü'lMaârif, 1988), 16-23.

23 Bir şeyin küçüklüğü, azlığı ve hakîrliği gibi manalar elde etmek için yapılan ism-i tasğîrlerin vezinleri sarf ilminde

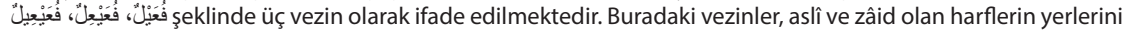
göstermek için değil, harf sayısı ile hareke ve sükûnların tertibini ifade etmektedir. Sîbeveyhi, el-Kitâb, 3/415-416; Celâlüddin Abdurrahman b. Ebî Bekir es-Süyûtî, Hem'u'l-hevâmi' fîşerhi cem'i'l-cevâmi', thk. Abdulhamid Hindâvî (Mısır: el-Mektebetu't-Tevfikiyye, ts.), 3/383; Abduhu er-Râcihî, et-Tatbîku's-sarfî (Riyad: Mektebetü'l-Maârif, 1999), 110. 


\subsection{1. نَحْرَجَ Bâbına Mülhak Olanlar}

ذَحْرَجْ bâbına mülhak olan altı bâb vardır ki bunlara rubâîye mülhak bâblar denir. Bunlar ya lâmu'l-fiilin tekrarı ya da fiile illet harfi eklenmesi suretiyle yapılır. Mülhak olan bu bâblar şu şekilde sıralanabilir: ${ }^{24}$

فَ فُلَلَ bâbı: Bu bâbda fiile lâmu'l-fiilin cinsinden bir harf ziyâde edilir. جَلَبَبَ (cilbâb giydirdi), شَمَلَّنَ (hızlı gitti) gibi.

فَوْ عَلَ bâbı: Bu bâbda fâu'l-fiil ile aynu'l-fiil arasında bir vâv harfi ziyâde edilir. جَوْرَبَ (çorap giydirdi), حَوْقَّل (yaşlandı) gibi.

بَفِ فَيْعَلَ bâbı: Bu bâbda fâu'l-fiil ile aynu'l-fiil arasında yâ harfi ziyâde edilir. (yardı), سَنْطَ (hakim oldu) gibi.

'فَحْوَ bâbı: Bu bâbda aynu'l-fiil ile lâmu'l-fiil arasında bir vâv harfi ziyâde edilir.

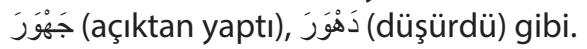

شَرَيَفِ فَعْيَلَ bâbı: Bu bâbda aynu'l-fiil ile lâmu'l-fiil arasında yâ harfi ziyâde edilir (ekinin yaprağını kesti), عَثْيَ (ayağı kaydı) gibi.

فَفْعَلَى bâbı: Bu bâbda lâmu'l-fiilden sonra yâ harfi ziyâde edilir. Ancak bu yâ harfi

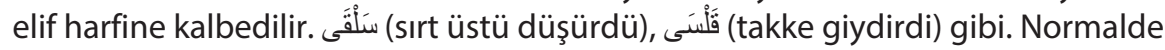
mülhak bâblarda i'lâl yapılmaz, ancak Arap dilinde kelimenin sonu sürekli değişime uğradığı için burada yapılan değişikliklere müsamaha ile yaklaşıımıştır.

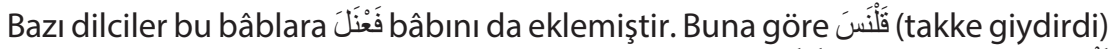

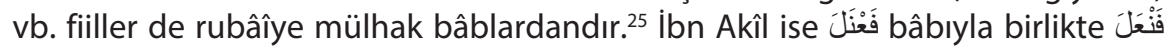
bâbını da bu bâblara ekleyerek rubâîye mülhak bâbların sayısını sekize çıkarmıştır. ${ }^{26}$

\subsection{2. تَنَحْرَجَ Bâbına Mülhak Olanlar}

نَحَحْرَجَ bâbına mülhak olan fiillerde ise ilhâk sebebiyle ziyâde edilen harfle beraber fiilin başında mutâvaat anlamı bildiren zâid bir tâ (ت) harfi bulunur. Ancak bu tür bâblarda ilhâk harfi fiilin başında ziyâde edilen tâ harfi değil, zâid olan diğer harftir. Çünkü fiilin başında bulunan tâ harfi, bu fiilleri نَخَحْرَ bâbına mülhak kılmak için değil, bir mana elde etmek için ziyâde edilmiştir ki o mana da mutâvaattır. Ayrıca ilhâk amacıyla ziyâde edilen harfler kelimenin başında bulunmayacağından bu tâ harfinin ilhâk harfi olmadığı anlaşıımış olur. ${ }^{27}$

24 Maksûd, 106; Binâu'l-ef'âl (Mecmûatu's-sarf içinde), (İstanbul: Şifa yayınevi, 2011), 76-80; Muhammed Said Salih, "Mefhûmu'I-ilhâk fi's-sarfi'l-Arabî", Mecelletu Buhûsi Külliyeti'I-Âdâb 106/1 (Temmuz 2016), 320-321.

25 Dunkûz (Dikgöz) Şemsuddin Ahmed, Şerhu'l-Merâh (Şerhân alâ Merâhi'l-Ervâh içinde), (Mısır: Şeriketu Mektebeti ve Matbaati Mustafa el-Bâbî el-Halebî ve Evlâdih, 1959), 23. Hamlâvî, Şeze'l-arf, 27.

26 İbn Akîl, Şerhu ibn Akîl alâ Elfiyyeti'bni Mâlik, 4/261.

27 Binâu'l-ef'âl, 88. 
نَحَحْرَجَbâbına mülhak olan fiiller beş bâb olup şunlardır:

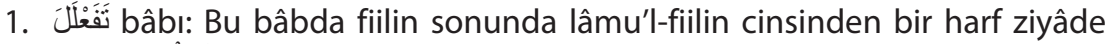
edilir. تَجَلْبَبَ (cilbâb giyindi) gibi.

2. نَفَهُ عَلْ bâbı: Bu bâbda fâu'l-fiil ile aynu'l-fiil arasında bir vâv harfi ziyâde edilir. تَجَوْرَبَ (çorap giyindi) gibi.

3. تَفَفْبَ bâbı: Bu bâbda fâu'l-fiil ile aynu'l-fiil arasında bir yâ harfi ziyâde edilir. تَشَيْنَنَ (şeytanlaştı) gibi.

4. تَفَعْوَلَ bâbı: Bu bâbda aynu'l-fiil ile lâmu'l-fiil arasında bir vâv harfi ziyâde edilir. تَرَ نْهَ (salınarak yürüdü) gibi.

5. تَفَعْلَى bâbı: Bu bâbda lâmu'l-fiilden sonra bir yâ harfi ziyâde edilir. Ancak ziyâde edilen yâ harfi daha sonra elif harfine kalbedilir. تَسَلْقَى (sırt üstü düştü) gibi. ${ }^{28}$

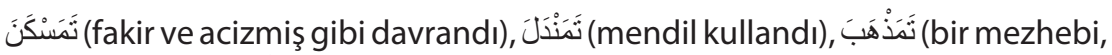
yolu benimsedi), نَدَرَّ (zırh giyindi) gibi fiillerin mülhak olup olmadığıyla ilgili dilcilerin büyük çoğunluğunun görüşü bunların mülhak vezinlerden olmayıp şâz

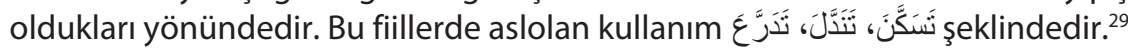

\subsection{3. إحْرَنْجَمَ Bâbına Mülhak Olanlar}

bâbına mülhak olanlar ise şu iki bâbdır: ${ }^{30}$

إِفْعَ bâbı: Bu bâbda sülâsî mücerred olan fiile üç harf ziyâde edilir. Bu harflerden ilk ikisi olan hemze ve nûn harfleri ilhâk amaciyla ziyâde edilen harfler değildir. İlhâk için ziyâde edilen harf lâmu'l-fiil cinsinden olup da ziyâde edilen harftir. إِقْحَنْسَسَ (göğsü fazlaca dışarı çıkıp sırtı içeri girdi), إسْحَنْكَ (karanlık iyice arttı) fiilleri gibi.

إِ إْعَلَْى bâbı: Bu bâbda da bir önceki bâbda olduğu gibi sülâsî mücerred fiile üç harf ziyâde edilir. Bu harfler hemze, nûn ve elif harfine kalbedilmiş olan yâ harfi-

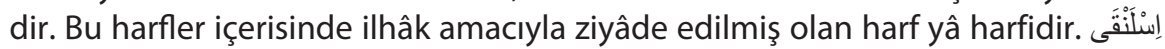
(sırt üstü düştü) fiili gibi.

28 Binâu'l-ef'âl, 84-85.

29 İbn Cinnî, el-Munsıf, 130; Cevherî, Sıhâh, "s-k-n", 503; Ebû Amr Cemâlüddîn Osmân b. Ömer b. Ebî Bekr b. Yûnus, eş-Şâfiye fi ilmeyi't-tasrîf ve'l-hat, thk. Salih Abdulazim eş-Şâir (Kahire: Mektebetu'l-Âdâb, 2010), 82; İbn Ya'îş, Şerhu'l-mufassal, 4/433.

30 Bk. Ebû Amr Cemâlüddîn İbnü'l-Hâcib Osmân b. Ömer b. Ebî Bekr b. Yûnus, eş-Şâfiye fi ilmi't-tasrîf (el-Vâfiye ile birlikte), thk. Hasan Ahmed el-Osman (Mekke: el-Mektebetu'I-Mekkiyye, 1995), 17; Binâu'l-ef'âl, 89-90; Ebu'l-Fidâ İmâduddîn İsmail b. Ali, el-Kunnâş fi fenneyi'n-nahvi ve's-sarf, thk. Riyâd b. Hasan (Beyrut: el-Mektebetu'l-Asriyye, 2000), 2/62. 


\section{2. İsimlerde İlhâk}

İsimlerden bazısının diğer bazısına ilhâkı da Arap dilinde rastlanan hususlardan biridir. İsimlerde yapılan ilhâk ya rubâî mücerrede ya rubâî mezîde ya humâsî mücerrede ya da humâsî mezîde ilhâk olmak üzere dört kısımda incelenebilir.

\subsubsection{Rubâî Mücerred İsimlere Yapılan İlhâk}

Rubâî mücerred isme mülhak olan kelimeler incelendiğinde bu kelimelerin şu

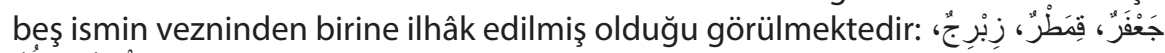
vezinleri.

Bu vezinlerden vَحَveznine mülhak olanlar şunlardır:

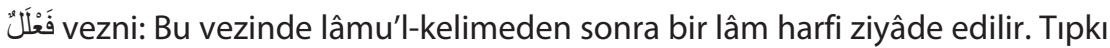

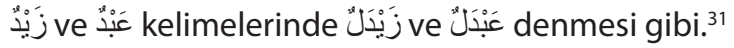

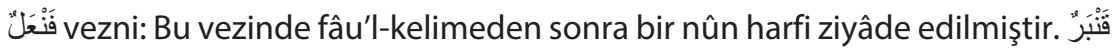
(bir kuş ismi) kelimesi gibi. ${ }^{32}$

vezni: Bu vezinde fâu'l-kelimeden sonra bir vâv harfi ziyâde edilmiştir. كَْْرَر (çok olan şey) kelimesi gibi.

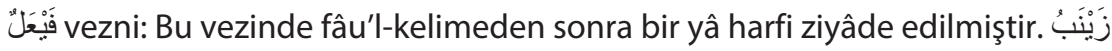
(bir kadın adı) kelimesi gibi. ${ }^{34}$

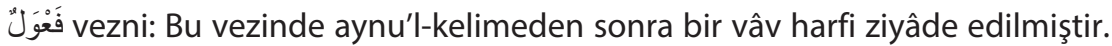
( حَدْوَلُ (küçük nehir) kelimesi gibi. ${ }^{35}$

فَعْلَّ vezni: Bu vezinde lâmu'l-kelimeden sonra bir elif harfi ziyâde edilmiştir. أرُطَى (bir bitki adı) kelimesi gibi. ${ }^{36}$

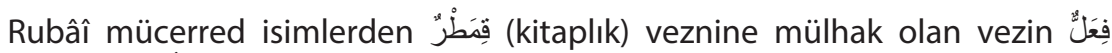
veznidir. Tıpkı خَدَبّ (iri adam) kelimesi gibi. ${ }^{37}$

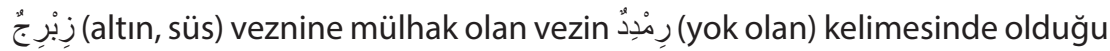
gibi $\operatorname{lin}^{2}$ veznidir. ${ }^{38}$

31 Nâzıru'l-Ceyş Muhammed b. Yûsuf b. Ahmed b. Abdiddâim et-Teymî, Temhîdü'l-kavâid bi şerhi teshîli'l-fevâid, thk. Ali Muhammed Fahir v.dğr. (Kahire: Dâru's-Selam, 2007), 10/4949.

32 Sîbeveyhi, el-Kitâb, 4/269.

33 İbn Yaîs, Şerhu'l-mufassal, 5/317.

34 Sîbeveyhi, el-Kitâb, 4/266.

35 Müberred, el-Muktadab, 2/107.

36 İbn Yaîs, Şerhu'l-mufassal, 3/383.

37 İbn Yaîş, Şerhu'I-mufassal, 4/158; Nâzıru'I-Ceyş, Temhîdü'l-kavâid, 10/4986.

38 İbn Yaîş, Şerhu'l-mufassal, 4/166; Ebû Hayyân Muhammed b. Yûsuf el-Endelüsî, Irrtişâfu'd-darab min lisâni'l-Arab, thk. Receb Osman Muhammed (Kahire: Mektebetu'l-Hâncî, 1998), 1/143; 


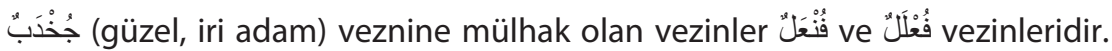
Birincisinde fâu'l-kelimeden sonra bir nûn harfi, ikincisinde ise lâmu'l-kelimenin

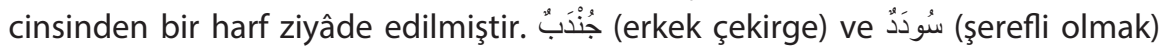
kelimelerinde olduğu gibi. ${ }^{39}$

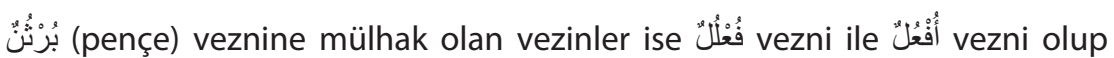
birincisinde lâmu'l-kelime cinsinden bir harf, ikincisinde ise fâu'l-kelimeden

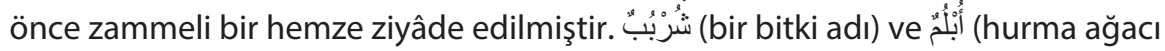
yaprağı) kelimeleri gibi. ${ }^{40}$

\subsubsection{Rubâî Mezîd İsimlere Yapılan İlhâk}

Rubâi mezîd isimlere mülhak olan kelimeler şu üç isimden birine ilhâk edil-

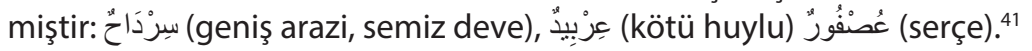

سِرْدَاحُ veznine ilhâk edilen vezinler şunlardır:

فِعْعَالْ vezni: Bu vezinde aynu'l-kelimeden sonra mîm ve elif harfleri ziyâde edilmiştir. هِرَْْمَاسِ (aslan) kelimesi gibi. ${ }^{42}$

فِفْنَالْ vezni: Bu vezinde aynu'l-kelimeden sonra nûn ve elif harfleri ziyâde edil-

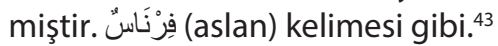

فِ فِعَلَع vezni: Bu vezinde lâmu'l-kelimeden sonra elif ve hemze harfleri ziyâde edilmiştir. عِلْبَّاء (boyundaki sinir) kelimesi gibi. ${ }^{44}$

فِ فِكَلَن vezni. Bu vezinde lâmu'l-kelimeden sonra elif ve nûn harfleri ziyâde edilmiştir. سِرَْْنَّن (kurt) kelimesi gibi. ${ }^{45}$

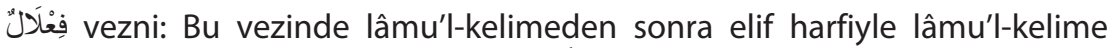

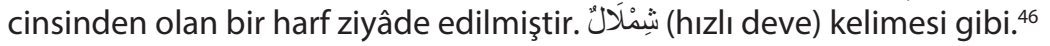

Rubâî mezid isimlerden عِرِبِيدُ veznine ilhâk edilen vezinler ise şunlardır:

فِنِعِيل vezni: Bu vezinde fâu'l-kelimeden sonra bir nûn harfi ve aynu'l-kelimeden sonra bir yâ harfi ziyâde edilir. صِنِِْيُ (cesur, kahraman) kelimesi gibi. ${ }^{47}$

فِفْلِيت vezni: Bu vezinde lâmu'l-kelimeden sonra bir yâ ve tâ harfi ziyâde edilmiştir. عِفْرِيت (habîs, hilekâr) kelimesi gibi. ${ }^{48}$

\footnotetext{
39 Sabbân, Hâşiyetü's-Sabbân ala şerhi'l-Eşmûnî, 3/140.

40 İbn Yaîş, Şerhu'l-mufassal, 4/166.

41 Nasır Hüseyin Ali, es-Sıyeğu's-sülâsiyye, 243.

42 İbn Yaîş, Şerhu'l-mufassal, 5/333.

43 Osman b. Cinnî, el-Hasâis (b.y.: el-Hey'etü'l-Mısriyyetü'l-Âmme, ts.), 3/194.

44 Sîbeveyhi, el-Kitâb, 3/214.

45 Sîbeveyhi, el-Kitâb, 3/216.

46 Nasır Hüseyin Ali, es-Sıyeğu's-sülâsiyye, 244.

47 Nasır Hüseyin Ali, es-Sıyeğu's-sülâsiyye, 243.

48 İbn Yaîş, Şerhu'l-mufassal, 5/328.
} 


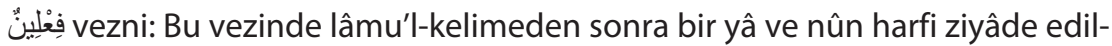
miştir. غِنْلِين (cehennemdekilerin vücudundan çıkan sıvı) kelimesi gibi. ${ }^{49}$

فِقِيُّن vezni: Bu vezinde aynu'l-kelime şeddelenip sonrasında bir yâ harfi ziyâde

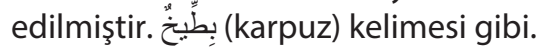

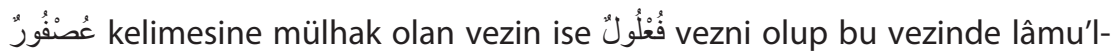
kelimeden sonra bir vâv harfi ile ondan sonra lâmu'l-kelime cinsinden bir harf

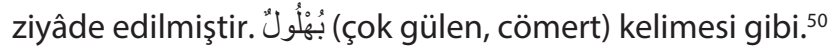

\subsubsection{Humâsî Mücerred İsimlere Yapılan IIlhâk}

Humâsî mücerred isimlere yapıllan ilhâklar, ya سَفَرْجَ (ayva) ya da قُرْطَعْبْ (bulut) isimlerinin vezinlerine yapılan ilhâklardır.

kelimesinin veznine yapılan mülhak vezinler şunlardır:51

i أَفَْْلْ vezni: Bu vezinde kelimenin başında bir hemze, fâu'l-kelimeden sonra ise bir nûn harfi ziyâde edilmiştir. أَنْنَ (amansız düşman) kelimesi gibi.

فَعَنَْى vezni: Bu vezinde aynu'l-kelimeden sonra bir nûn harfi ile kelimenin sonunda bir elif harfi ziyâde edilmiştir. حَبَنْ (kısa boylu şişman) kelimesi gibi.

فَعَعَعْ vezni. Bu vezinde aynu'l-kelimeden sonra bir nûn harfi ve aynu'lkelimenin cinsinden bir harf ziyâde edilmiştir. عَفْقَ (kum tepesi) kelimesi gibi.

فَعَعَلْ vezni: Bu vezinde aynu'l-kelime ile lâmu'l-kelimenin cinsinden birer harf ziyâde edilmiştir. صَصَحْمَ (kısa boylu kaba kişi) kelimesi gibi.

kقِ قِطَعْبٌ kelimesinin veznine yapılan mülhak vezinler ise şunlardır:

إنْفَعْلِ vezni: Bu vezinde kelimenin başında hemze ve nûn harfleri ziyâde edilmiştir. إِنَ (kendisiyle çokça övünen) kelimesi gibi.

فِنْعَمُو vezni: Bu vezinde fâu'l-kelimeden sonra bir nûn harfi ile kelimenin sonunda bir vâv harfi ziyâde edilmiştir: حِنَُّو (kısa boylu şişman kişi) kelimesi gibi.

إِفْعَلٌّ vezni: Bu vezinde kelimenin başında bir hemze, sonunda ise lâmu'lkelimenin cinsinden bir harf ziyâde edilmiştir. إِّرَّب (kısa boylu) kelimesi gibi.

\subsubsection{Humâsî Mezîd İsimlere Yapılan ilhâk}

Humâsî mezîd isimlere mülhak olan kelimeler şu iki ismin veznine ilhâk edilen-

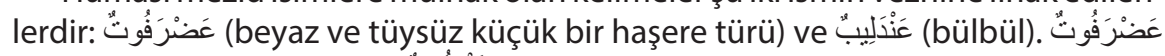

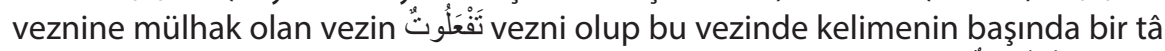

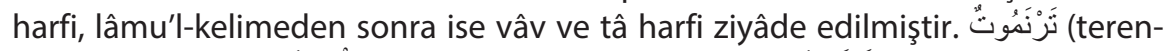

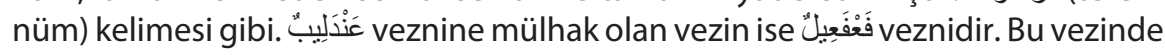

49 Nasır Hüseyin Ali, es-Sıyeğu's-sülâsiyye, 244.

50 Ebû Hayyân, Irtişâfu'd-darab, 1/143.

51 İbn Akîl, Şerhu İbn Akîl alâ Elfiyyeti'bni Mâlik, 4/138; Süyûtî, Hem'u'l-hevâmi' fi şerhi cem'i'l-cevâmi', 3/460. 
fâu'l-kelime ile aynu'l-kelimenin cinsinden birer harf ile lâmu'l-kelimeden önce bir yâ harfi ziyâde edilmiştir. مَزْمَرِيس (akıllı, dâhî) kelimesi gibi. ${ }^{52}$

\section{4. İlhâkın Kıyâsî ya da Semâî Oluşu}

Arap dili gramerinde dilciler arasında meydana gelen pek çok tartışmanın kaynağının semâ' ve kıyâs delillerini işletme metodundaki ihtilaflardan kaynaklandığı bilinmektedir. İlhâk meselesinde de mülhak kelimelerin ilhâkının semâî veya kıyâsî oluşu, birçok dilci tarafından bu tür kelimelerin Araplar tarafından yaygın bir şekilde kullanılıp kullanılmadığıyla ilişkilendirilerek ele alınmıştır.

Yukarıda verilen mülhak vezinlerin semâî olup kıyâsa konu olamayacağı ya da bu konuda kıyâsın işletilebileceği hususu dilciler arasında araştırılagelmiştir. Ebû Osman el-Mâzinî (ö. 249/863), Ebû Ali el-Fârisî (ö. 377/987), İbn Cinnî (ö. 392/1002), İbn Ya'îş (ö. 643/1245) gibi kadim dilciler, mülhak vezinler içerisinde lâmu'l-fiilin tekrarı ile yapılanları kıyâsî olarak görmüşlerdir. ${ }^{53}$ Çünkü bu şekilde yapılan ilhâklar, Arap dilinde kıyâsa konu olacak kadar yaygındır. Buna göre جَلْبَبَ

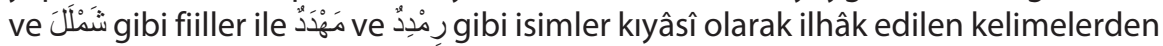

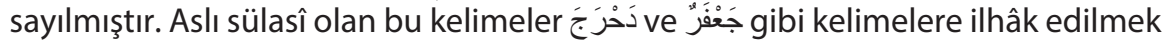
istendiğinde aslî harf olan lâmu'l-kelimenin cinsinden bir harf ziyâde edilmiş ve böylece aslî harfin tekrarı mülhakun bih olan mücerred kelimenin son aslî harfine benzemiş olur. ${ }^{54}$ Durum böyle olunca ضَرَرَبَبَ fiilini نَحْرَجَ filine mülhak kı demek caiz olur. Nitekim İbn Cinnî, Ebû Ali el-Farisîye mülhaklar içerisinde kıyâsî olanla olmayanı sorduğunu, onun da bir şairin bugün ihtiyaç duyması halinde

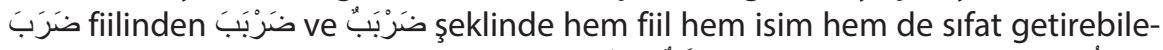

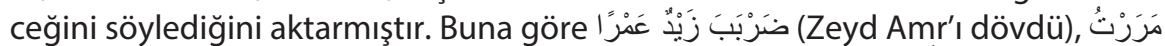

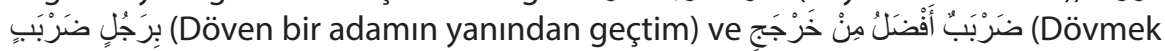
çıkmaktan iyidir) gibi ifadeler kullanmak caizdir. İbn Cinnî, Fârisî'den yaptığı

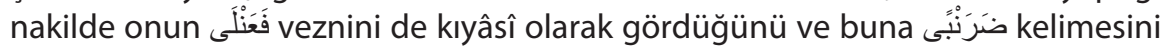
örnek olarak verdiğini nakleder. ${ }^{55}$ Yaygın kabul edilen bu tür mülhak kullanımların dışında kalanlar ise kıyâsî değil semâî olarak kabul edilmiştir. Buna göre

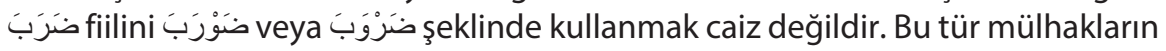
kabulü, ancak Araplar tarafından kullanılmaya bağlıdır.

Kıyâsî olarak kabul edilen mülhak kullanımlar neticesinde elde edilen kelimelerin Arap dilinden sayılıp sayılamayacağı hususunda ise dilciler arasında ihtilaf vardır. Halil b. Ahmed (ö. 175/791), bu tür mülhaklar içerisinde Arapların kullanmış olduklarının Arap kelamından sayılacağını, geri kalanların ise dilciler tarafından bir nevi alıştırma için türetildiğini ve Arap kelamından sayılmayacağını ifade etmiştir. Ebû Ali el-Farisî ise bunların Arap kelamından olduğunu iddia etmiştir.

52 Nasır Hüseyin Ali, es-Sıyeğu's-sülâsiyye, 243-245.

53 İbn Cinnî, el-Munsıf, 43-44; İbn Ya'îş, Şerhu'I-mufassal, 4/430.

54 ìbn Cinnî, el-Munsıf, 43.

55 İbn Cinnî, el-Munsıf, 43-44. 
Mâzinî ise bu hususta şöyle bir tafsilata gitmiştir: Arapların sıklıkla kullandığı mülhak vezinler kıyâsî kabul edilip Arap dili içerisinde değerlendirilir. Kullanımı az olup Araplar tarafından kullanılmamış olanlar ise kıyâsî kabul edilmeyip Arap dili içerisinde değerlendirilmezler. ${ }^{56}$

Klasik dilciler, konuya semâ' ve kıyâs ayrımı gözeterek yaklaşıp mülhakları yaygın kullanımı olanlar ve az kullanılanlar şeklinde ikili bir tasnife tabi tutmaktadırlar. Bu alanda araştırma yapan muasır bazı dilciler ise mülhak bâblarda semâîkıyâsî ayrımının doğru olmadığını savunup bunu kadîm dilcilerin kitaplarında zikrettikleri ضَرْبَبَ gibi örneklerin Arap dilinde kullanımının olmaması ile gerekçelendirmektedirler. Bu görüşe göre mülhaklarda kıyâsî olma özelliği bulunmamakta ve bu sebeple de mülhak olan kelimeler Arapların kullandıklarıyla sınırlı olmaktadır. ${ }^{57}$

\section{5. İlhâkın Amaçları}

Bir fiilin diğer bir fiile ya da bir ismin diğer bir isme ilhâk edilmesinde birtakım amaçlar bulunmaktadır. Araplar, nasıl ki farklı manalar elde etmek amacıyla kelimeye o kelimenin aslından olmayan harfler ziyâde etmişlerse bir takım amaçlarla da bir kelimeyi diğer bir kelimeye mülhak kılmışlardır. Daha önce ilhâk amacıyla yapılan ziyâdenin mana elde etmek üzere yapılmadığına işaret edilmişti. Çünkü ilhâkta gözetilen amaç manadan ziyâde lafza yöneliktir.

Arapların bir kelimeyi diğerine mülhak kılarken gözettiği amaçlar şunlardır:

\subsection{Kelime Zenginliği Sağlamak}

Bir dilin kelimelerinin çokluğu o dilin zenginliğini, ifade kuvvetini ve çeşitliliğini gösteren unsurlardan biridir. Kelimelerin çokluğu o dili konuşan kişiye kendisini ifade etme hususunda geniş bir alan açar. Araplar da dillerini zenginleştirmek ve kelime sayısını çoğaltmak amacıyla kelimeler için vaz ettikleri vezinleri çoğaltmak ve bu vezinlerde farklı kelimeler türetmek suretiyle bunu gerçekleştirmişlerdir. İbn Ya'îş, Arapların kelime içerisinde ziyâde ettikleri harflerin amaçlarını ifade etme sadedinde "...Ziyâde ya bir mana ifade etmek ya da dilde tevessü' sağlamak içindir"58 demektedir. İbn Ya'îş'in "dilde tevessü' sağlamak" ifadesindeki kastı, dilde yeni vezinler ihdâs edip bu vezinlere uygun kelimeler türeterek dili kelimeler açısından zenginleştirmektir.

\section{2. Şiirlerde Vezin Uyumu Sağlamak}

Şiirleri cazip ve güzel kılan, ona ahenk katan, söylendiğinde muhatabı coşturan önemli unsurlardan biri de şüphesiz ki vezindir. "Şiirde vezin, hecelerin ya da uzun ve kısa hecelerin belirli miktarlarda tekrarına dayanan, müzikal ve fonetik

56 Ebû Hayyân, Irtiş̧âfu'd-darab, 1/234; Süyûtî, Hem'u'l-hevâmi', 1/121.

57 Nasır Hüseyin Ali, es-Sıyeğu's-sülâsiyye, 253.

58 İbn Ya'îş, Şerhu'l-mufassal, 4/430. 
ahengi sağlayan kalıplar dizisidir. Şiiri nesirden ayıran en önemli unsur vezindir." ${ }^{59}$ Arap dilinde söylenen bir şiirin vezin uyumu için bazen kelime üzerinde birtakım değişikliklere ihtiyaç duyulur. Bu uyumu sağlamak için kullanılan kelimelerden bazısı mülhak kelimelerdir. Özellikle yukarıda mülhakların kıyâsî kısmında değerlendirilen bâblardan getirilen kelimeler bazen şaire vezin uyumunu sağlama hususunda son derece yardımcı olmaktadır. ${ }^{60}$

\subsection{Yabancı Kelimeleri Arapçalaştırmak}

Arap dilindeki ilhâkın önemli amaçlarından biri de yabancı kökenli kelimeleri Arapçalaştırma (ta'rîb) ve bu kelimelere Arap dilinin özelliklerini kazandırma hususunda kolaylık sağlamasıdır. Buna göre yabancı olan kelimeye mülhak bâblarda ziyâde edilen harflerin katılması suretiyle kelime Arapçalaşmış olmak-

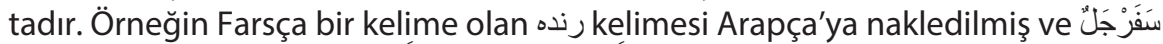

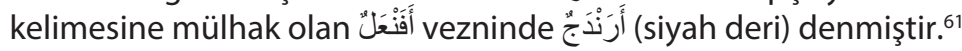

\section{Mülhak Bâbların Mezîd Bâblardan Farkı}

Arap diline dair yazılan eserler incelendiğinde mülhak bâbların mezîd bâblardan ayrı olarak ele alındığı görülmektedir. Bunun altında yatan temel sebep, mülhak bâblarda ziyâde edilen harflerin mezîd bâblarda ziyâde edilen harflerden fonksiyon olarak farklı olmasıdır. Mezîd bâblarda ziyâde edilen harfler, kelimeye farklı bir mana katmak üzere ziyâde edilmişken mülhak bâblardaki ziyâdeler bir kelimeyi diğer bir kelimeye vezin yönüyle benzetmek üzere ziyâde edilmiştir. ${ }^{62}$ Sözgelimi أَكْرَمَ fiilindeki hemzenin ziyâde edilmesi ile جَلْبَ fiilinde ziyâde edilen bâ harfinin ziyâde edilmesi, bu harflerin icrâ ettikleri görev açısından farklıdır. Her ne kadar her iki fiilin harf sayısı, hareke ve sükûnlarının tertibi aynı olsa da fiilinin نَحْرَجَ fiiline mülhak olduğu söylenemez. Çünkü bu bâbda gelen fiillerdeki ilhâkta

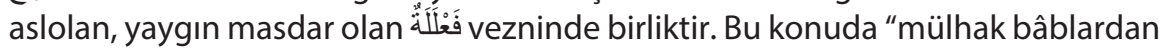
olan fiillerin ilhaktan önceki manasıyla ilhaktan sonraki manası farklı olabilmektedir. Dolayısıyla ilhâkın da mana yönüyle bir fonksiyonu bulunmaktadır. Bu sebeple de mülhaklar mezîd bâblardan sayılmalıdır." şeklinde bir itiraz yapılamaz. Çünkü her ne kadar mülhak kelimenin ilhaktan önceki manasıyla sonraki manası farklı olabilmekteyse de ilhâk için ziyâde edilen harfin bu manayı katması ile mezîd bâblardaki zâid harfin bu manayı katması arasında fark vardır. Şöyle ki; mezîd bâblarda ziyâde edilen harf o manayı kelimeye katmak için vaz edilmiştir ve ziyâde edildiği kelimelerde genelde o manayı kelimeye katmaktadır. Örneğin if'âl bâbının hemzesi fiile müteaddîlik vb. manalar katmak, mufâale bâbındaki elif harfi fiile işteşlik vb. manalar katmak gibi manalar için vaz edilmiştir ve bu harflerin ziyâde edildiği fiillerde bu manaları sürekli olarak icrâ ederler. Hâlbuki

59 İsmail Durmuş, "Vezin”, Türkiye Diyanet Vakfı Islam Ansiklopedisi, (Ankara: TDV Yayınları, 2013), 43/77-79.

60 Radî el-Esterâbâdî, Şerhu'ş-Şâfiye, 1/52.

61 Muhammed b. Ahmed el-Ezherî, Tehzîbu'l-luga, thk. Muhammed İvaz (Beyrut: Dâru İhyâi't-Turâsi'l-Arabî, 2001), "Bâbu'l-cîm ve'd-dâl", 11/170.

62 Ebu'l-Fidâ, el-Kunnâş, 2/62. 
örneğin جَلْبَبَ fiilinin sonundaki bâ harfi fiile bir mana katmak için değil, sırf bu fiili sûreten نَحْرَجَ fiiline benzetmek için ziyâde edilmiştir. İsimlerde de durum aynıdır. Sözgelimi ضَنَارِبْ kelimesinde ziyâde edilen elif harfi veya مَنْحِدُ kelimesinde ziyâde edilen mîm harfi bu kelimelere fiili meydana getiren kişiyi ifade etme veya fiilin meydana geldiği yeri ve zamanı gösterme yönünden bir mana katar ve bütün sülâsî mücerred fiillerde aynı vazifeyi icrâ ederler. Buna karşılık أَرْطَى (bir bitki adı) kelimesindeki elif harfinin ziyâde edilmesinin sebebi bu kelimeye bir mana katmak değil, sadece bu kelimeyi "جَفَ kelimesine benzetmektir. Kaldı ki mülhak bâblardan olan kelimelerden kiminin ilhâk harfi çıkarıldığında herhangi bir kulla-

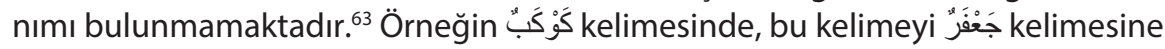
ilhâk etmek amacıyla bir vâv harfi ziyâde edilmiştir. Bu vâv harfinin kelimeden çıkarılması halinde kelime كَكَبْ jolarak kalacaktır ki böyle bir kelime Arap dilinde bulunmamaktadır. زَيْنَبُ kelimesinde de durum aynıdır. İlhâk harfi çıkarıldığında hiçbir anlamı olmayan bir lafza dönüşen bu kelimelerdeki ilhâk harfinin kelimeye yeni bir mana katmasından bahsedilemeyeceği açıktır. Bütün bunlardan da anlaşılmaktadır ki mülhak bâblardaki ziyâdeler ile mezîd bâblardaki ziyâdeler birbirinden farklıdır ve bu sebeple de aynı kategoride değerlendirilemezler.

\section{Mülhak Kelimelerin Mücerredleriyle İlgisi}

Kendisinde harf ziyade edilmiş olan mülhak kelimelerle bu harfin hazfedilmesi durumunda ortaya çıkan kelimeler arasında ne tür bir ilişki olduğu hususu da konunun ele alınması gereken önemli yönlerinden biridir. Mülhak fiillerle bu fiillerin mücerred hali karşılaştırıldığında bazı mülhakların fiilin mücerred haliyle bir anlam ilgisinin bulunduğu bazılarında ise bu ilginin bulunmadığı anlaşımaktadır. Sözgelimi عَحْرَجَ عَلْونَ fiiline mülhak olan (adres yazdı, kitap vb. bir şeye isim verdi, başıık yazdı) fiili, mücerred fiil olan عَلَن (alenî oldu, açık oldu) ${ }^{64}$ fiilinden türetilmiştir ve bu iki fiil arasında bir anlam ilişkisi bulunduğu açıktır. Aynı şekilde "çoğaldı, çok oldu" anlamına gelen fَili ile bu fiille aynı kökten gelen كوَثْرُ (çok fazla olup yükselen toz; sayı, hacim ve ölçü olarak çok olan her şey, hayrı bol olan) ${ }^{65}$ kelimesi arasında da anlam yönünden bir benzerlik bulunmak-

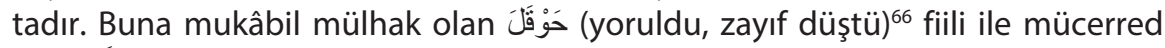
olan حَقَ (tarlayı ekti) ${ }^{67}$ fiili arasında anlam yönünden bir alaka bulunmamaktadır. Bazı mülhak kelimelerde bulunan ziyade harfin çıkarılması durumunda ise

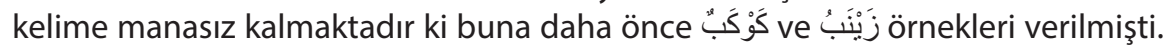
Verilen bu örneklerden de anlaşılmaktadır ki ilhâk amacıyla yapılan ziyadeler neticesinde kelime bazen farklı bir anlam kazanmaktadır. Ancak bu durum, ilhâk

63 Radî el-Esterâbâdî, Şerhu'ş-Şâfiye, 1/54.

64 Cevherî, Sihâh, "'a-I-n", 739.

65 İbn Manzûr, Lisânu'I-Arab, "k-s-r", 5/133; Ebü'I-Bekâ el-Kefevî, el-Külliyyât, thk. Adnan Derviş-Muhammed el-Mısrî (Beyrut: Müessesetu'r-Risâle, ts.), 742.

66 Ezherî, Tehzîbü'I-luga, "Bâbu'I-hâ ve'I-mîm”, 4/32; İbn Manzûr, Lisânu'l-Arab, "ḥ- ḳ-l", 11/161.

67 Ebü'l-Kâsım Mahmûd b. Ömer b. Muhammed el-Hârizmî ez-Zemahşerî, el-Fâik fí garîbi'l-hadîs, thk. Ali Muhammed el-Becâvî-Muhammed Ebü'l-Fadl (Lübnan: Dâru'l-Marife, ts.), 1/298. 
olgusunda asıl amacın kelimeye bir mana katmak değil de bir lafzı diğer lafza benzetmek olduğuna dair görüşü değiştirmemektedir. Çünkü yukarıda da ifade edildiği üzere mülhak bâblarda ziyade edilen harfler kelimelere yeni manalar katma hususunda örneğin if'âl bâbının hemzesi veya tefâ'ul bâbının tâ ve elifi gibi değildir. Nitekim Radıyyüddîn el-Esterâbâdî de bu duruma dikkat çekerek meselenin bu yönünü şu şekilde ifade etmektedir: "Zannedildiği gibi bizler, ilhâktaki ziyade ile mananın değiş̧meyeceğinin zorunlu olduğunu ifade etmiyo-

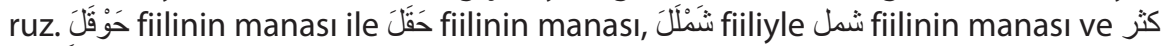
ile كَوَْْ kelimelerinin manası ${ }^{68}$ birbirinden farklı iken bunu nasıl söyleyebiliriz ki!"69

\section{Sonuç}

Arap dilinde kullanılan ve kendisinde aslî olmayan bazı harfler taşıyan, ancak mezîd bâblardan sayılmayan mülhak bâbların varlığı ilk dönemlerden beri dilcilerin dikkatini çekmiştir. Araplar tarafından dilde zenginlik sağlamak amacıyla kullanılan bu bâblar incelendiğinde rastgele bir kullanımın olmadığı, aksine bu bâblarda bazı temel ilkelerin ve sınırlamaların bulunduğu dikkat çekmektedir ki bunlardan bazıları şunlardır:

1. Kelime türlerinden fiil ve isimlerde ilhâk olgusuna rastlanırken harflerde böyle bir durum söz konusu olmamıştır.

2. Mülhak olan kelimenin kendisine ilhâk edildiği bir asıl (mülhakun bih) mutlaka bulunmaktadır.

3. İlhâk sadece sülâsî ve rubâî olan isim ve fiillerde icrâ edilmiştir.

4. İlhâk sadece bir veya iki harf ziyâdesiyle yapılmıştır.

5. Med harflerinin ziyâde edilmesi sûretiyle yapılan ilhâklarda bu harfler kelimenin sonunda ziyâde edilmiştir.

6. İlhâk için ziyâde edilen harf, mülhakun bih olan kelimede aslî olan bir harfe karşılık getirilmiştir.

7. Mülhakun bih olan kelimede ziyâde edilen harfler varsa mülhak olan kelimede de aynı harfler aynı yerde ziyâde edilmiştir.

Öte yandan kadîm dilciler, mülhak bâbları, yaygın kullanımının olup olmamasına göre semâ'î ve kıyâsî şeklinde iki kısma ayırmışlardır. Buna karşılık modern bazı çalışmalarda, kıyâsî olarak gösterilen mülhaklar için verilen ضَرْبَبَ vb. örneklerin Araplar tarafından kullanılmamış olması sebebiyle semâ'î-kıyâsî ayrımının doğru olmadığı, bütün mülhakların semâ'î olduğu ifade edilmiştir. Ancak semâîkıyâsî ayrımı yapan Mâzinî, Fârisî, İbn Cinnî ve İbn Ya'îş gibi dilciler bu bâblardan

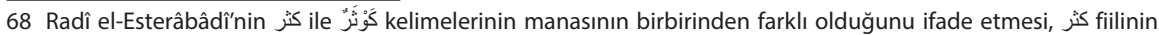

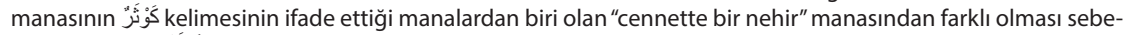

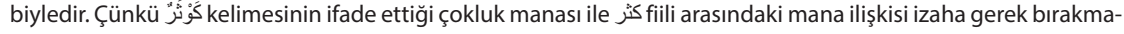
yacak kadar açıktır.

69 Radî el-Esterâbâdî, Şerhu'ş-Şâfiye, 1/52. 
gelen mülhak kelimelerin yaygınlığını kıyâsa temel olarak kabul etmişlerdir ki kanaatimizce doğru olan da budur. Nitekim bir şey kıyâsa konu olacak seviyeye ulaştığında artık o kıyâsa uygun olarak kullanılan kelimelerin Araplar tarafından mutlaka kullanılmış olması gibi bir şart aranmaz. Bu durum fâilin merfû, mef'ûlün mansûb olarak kabul edilmesinden sonra merfû olarak kullanılan bir fâilin ya da mansûb olarak kullanılan bir mef'ûlün bizzat kendisinin Araplar tarafından kullanılıp kullanılmadığına bakılmamasına benzer. Ayrıca özellikle şiir vb. edebî eserlerde bu tür mülhakların kolaylık sağlaması da bu tür bâbların kıyâsî kabul edilmesinin evlâ olduğunu göstermektedir.

Mülhak kelimenin manası ile ziyade edilen harfin çıkarılması durumunda kelimenin ifade ettiği mana arasında bazı münasebetlerin olduğu, mülhak bâblarda bazen mananın değişmeyip sadece mücerred kelimenin manasına mübâlağa kattığı gibi hususlar dikkat çekmektedir. Bu yönüyle de mülhak kelimelerin mezîd kelimelerle aynı özelliklere sahip olduğu gibi bir izlenim oluşmaktadır. Ayrıca bu durum ilk bakışta, ilhâkın temel felsefesinin bir kelimeyi kendisinden daha fazla harfe sahip olan başka bir kelimeye sırf şekil açısından benzetmek olduğu görüşünü nakzediyor gibi bir izlenime sebep olabilmektedir. Ancak mezîd bâblardaki ziyadenin mana ifade etme hususundaki sürekliliği (ıttırâd) göz önünde bulundurulduğunda mülhak bâblardaki ziyadenin böyle bir özellik taşımaması sebebiyle mezîd bâblardaki ziyadeden ayrı tutulması gerektiği görüşü öne çıkmaktadır. 


\section{Kaynakça}

Akşehrî, Ali b. Osman er-Rûmî. Telhîsu'I-Esâs (Şurûhu metni'l-Binâ içerisinde). İstanbul: Şifa Yayınevi, 2014.

Ayşe İbrahim el-Mehdî. Zâhiretü'l-ilhâk fi's-sarfi'l-Arabî. Sudan: Omdurman İslam Üniversitesi, Külliyetü'l-Lüga el Arabiyye, Yüksek Lisans Tezi, ts.

Binâu'l-ef'âl (Mecmûatu's-sarf içinde). İstanbul: Şifa Yayınevi, 2011.

Cevherî, İsmail b. Hammâd. Mu'cemu's-Sıhâh. Beyrut: Daru'l-Marife, 2012.

Dunkûz (Dikgöz), Şemseddin Ahmed. Şerhu'l-Merâh (Şerhân alâ Merâhi'l-Ervâh içinde). Mısır: Şeriketu Mektebeti ve matbaati Mustafa el-Bâbî el-Halebî ve Evlâdih, 1959.

Durmuş, İsmail. "Vezin". Türkiye Diyanet Vakfı İslam Ansiklopedisi. 43/77-79. Ankara: TDV Yayınları, 2013.

Ebû Hayyân, Muhammed b. Yûsuf el-Endelüsî. Irtişâfu'd-darab min lisâni'l-Arab. thk. Receb Osman Muhammed. 3 Cilt. Kahire: Mektebetu'l-Hâncî, 1998.

Ebu'I-Fidâ, İmâduddîn İsmail b. Ali. el-Kunnâş fî fenneyi'n-nahvi ve's-sarf. thk. Riyâd b. Hasan. Beyrut: el-Mektebetu'l-Asriyye, 2000.

Esterâbâdî, Radıyyüddîn Muhammed b. el-Hasen. Şerhu'ş-Şâfiye. thk. Muhammed Nûr el-Hasan v.dğr. 4 Cilt. Beyrut: Dâru'I-Kütübi'l-IImiyye, 1975.

Eşmûnî, Ali b. Muhammed. Menhecü's-sâlik ilâ Elfiyyeti'bni Mâlik. 4 Cilt. Beyrut: Dâru'lKütübi'l-IIlmiyye, 1998.

Ezherî, Muhammed b. Ahmed. Tehzîbu'l-luga, thk. Muhammed İvaz. 15 Cilt. Beyrut: Dâru İhyâi't-Turâsi'l-Arabî, 2001.

Fîrûzâbâdî, Muhammed b. Yakub. el-Kâmûsu'I-muhît. Beyrut: Dâru'I-Erkam b. Ebi'l-Erkam, ts.

Hamlâvî, Ahmed b. Muhammed. Şeze'l-arf fî fenni's-sarf. thk. Nasrullah Abdurrahman Riyad: Mektebetu'r-Rüşd, ts.

İbn Akîl, Bahâuddin Abdullah. Şerhu ibn Akîl alâ Elfiyyeti'bni Mâlik. thk. Muhammed Muhyiddin Abdulhamid. 4 Cilt. Kahire: Dâru't-Turâs, 1980.

İbn Cinnî, Osman. el-Munsıf. b.y.: Daru İhyâi't-Turâsi'I-Kadîm, 1954.

İbn Cinnî, Osman. el-Hasâis. b.y.: el-Hey'etü'l-Mısriyyetü'l-Âmme, ts., 194.

İbn Hişâm, Cemâlüddîn Abdullah b. Yûsuf b. Ahmed b. Abdillâh b. Hişâm el-Ensârî. Muğni'llebîb 'an kütübi'l-e'ârîb. thk. Mazin Mübarek-Muhammed Ali Hamdullah. Dimaşk: Dâru'l-Fikr, 1985.

İbn Manzûr, Ebü'l-Fazl Cemâlüddîn Muhammed b. Mükerrem b. Alî b. Ahmed. Lisânu'lArab. 15. Cilt. Beyrut: Dâru Sâdır, 1994.

İbn Hişâm, Cemâlüddîn Abdullah b. Yûsuf b. Ahmed b. Abdillâh el-Ensârî, Şerhu Katrinnedâ ve belli's-sadâ, thk. Muhammed Muhyiddin Abdulhamid, (Beyrut: el-Mektebetu'lAsriyye, 2010), 312.

İbn Kemâlpaşa, Şemseddin Ahmed. el-Felâh fî şerhi'l-Merâh (Dunkûz şerhiyle beraber Şerhân ale'l-Merâh kitabı içerisinde). Mısır: Şeriketu Mektebeti ve Matbaati Mustafa el-Bâbî el-Halebî ve Evlâdih, 1959. 
İbnü'l-Hâcib, Ebû Amr Cemâlüddîn Osmân b. Ömer b. Ebî Bekr b. Yûnus. eş-Şâfiye fi ilmeyi'ttasrîf ve'l-hat. thk. Salih Abdulazim eş-Şâir. Kahire: Mektebetu'l-Âdâb, 2010.

İbnü'l-Hâcib, Ebû Amr Cemâlüddîn Osmân b. Ömer b. Ebî Bekr b. Yûnus. eş-Şâfiye fi ilmi'ttasrîf (el-Vâfiye ile birlikte). thk. Hasan Ahmed el-Osman. Mekke: el-Mektebetu'lMekkiyye, 1995.

İbn Ya'îş, Muvaffakuddîn Yaîş b. Alî. Şerhu'l-mufassal li'z-Zemahşerî. thk. Emîl Bedî’ Yakub. 5 Cilt. Beyrut: Dâru'l-Kütübi'l-İlmiyye, 2001.

İbrahim Mustafa vd., el-Mu'cemu'l-Vasît. byy: y.y., ts.

Kabâve, Fahruddin. Tasrîü̈l-esmâ ve'l-ef'âl. Beyrut: Mektebetü'l-Maârif, 1988.

Kefevî, Ebü'l-Bekâ. el-Külliyyât. thk. Adnan Derviş-Muhammed el-Mısrî. Beyrut: Müessesetu'r-Risâle, ts.

Lübdî, Muhammed Semir Necîb. Mu'cemu'l-mustalahâti'n-nahviyye ve's-sarfiyye. Beyrut: Müessesetu'r-Risale, 1985.

Maksûd (Mecmûatu's-sarf içinde). İstanbul: Şifa Yayınevi, 2011.

Mehdî, İbn Ali. Ebniyetü'I-ilhâk fi's-Sıhâh. Mekke: Ümmü'I-Kurâ, Külliyetü'I-Lüga el Arabiyye, Yüksek Lisans Tezi, 1996.

Muhammed Said Salih. "Mefhûmu'l-ilhâk fi's-sarfi'l-Arabî". Mecelletu Buhûsi Külliyeti'l-Âdâb 106/1 (Temmuz 2016), 320-321.

Müberred, Ebu'l-Abbâs Muhammed b. Yezîd. el-Muktadab. thk. Muhammed Abdulhalık Azîme. 4 Cilt. Beyrut: Âlemu'l-Kütüb, ts.

Müberred, Ebu'l-Abbâs Muhammed b. Yezîd. el-Kâmil fi'l-luga ve'l-edeb. thk. Muhammed Ebu'l-Fadl İbrahim. 4 Cilt. Kahire: Dâru'I-Fikri'l-Arabî, 1997.

Nasır Hüseyin Ali. es-Sıyeğu's-sülâsiyye. Dimaşk: el-Matbaatu't-Teâvuniyye, 1989.

Nâzıru'l-Ceyş, Muhammed b. Yûsuf b. Ahmed b. Abdiddâim et-Teymî. Temhîdü'l-kavâid bi şerhi teshîli'l-fevâid, thk. Ali Muhammed Fahir v.dğr. 11 Cilt. Kahire: Dâru's-Selam, 2007.

Râcî Esmer. el-Mu'cemu'l-mufassal fî ilmi's-sarf. Beyrut: Dâru'I-Kütübi'I-Illmiyye, 1997.

Râcihî Abduhu. et-Tatbîku's-sarfî. Riyad: Mektebetü'l-Maârif, 1999.

Sabbân, Muhammed b. Ali. Hâşiyetü's-Sabbân ala şerhi'I-Eşmûnî ala Elfiyyeti'bni Mâlik. 3 Cilt. Beyrut: Dâru'l-Kütübi'l-İlmiyye, 1997.

Sîbeveyhi, Ebû Bişr Amr b. Osmân b. Kanber el-Hârisî.el-Kitâb. thk. Abdusselam Muhammed Harun. 4 Cilt. Kahire: Mektebetu'l-Hâncî, 1988.

Süyûtî, Celâlüddin Abdurrahman b. Ebî Bekr. Hem'u'l-Hevâmi' fi Şerhi Cem'i'l-Cevâmi'. thk. Abdulhamid Hindâvî. 3 Cilt. Mısır: el-Mektebetu't-Tevfîkiyye, ts.

Zemahşerî, Ebü'l-Kâsım Mahmûd b. Ömer b. Muhammed el-Hârizmî. el-Fâik fî garîbi'I-hadîs. thk. Ali Muhammed el-Becâvî-Muhammed Ebü'l-Fadl. 4 Cilt. Lübnan: Dâru'l-Marife, ts. 